\title{
Evidence Based Abortion Stigma Reduction Using Radio Drama in Nigeria
}

\author{
Eremutha Awasighe Francis ${ }^{1, *}$, Okosun Onaburekhalen Thankgod ${ }^{1}$, Gabriel Veronica Chizoba ${ }^{1}$, \\ Diakpomrere Oghenevweta Vincent ${ }^{2}$
}

\author{
${ }^{1}$ Women Friendly Initiative, Kuje Area Council, Abuja FCT, Nigeria \\ ${ }^{2}$ Department of Theatre Arts and Mass Communication, University of Benin, Nigeria
}

Copyright $@ 2019$ by authors, all rights reserved. Authors agree that this article remains permanently open access under the terms of the Creative Commons Attribution License 4.0 International License

\begin{abstract}
A substantial number of Nigerian women/ girls have unwanted pregnancies due to their low contraceptive prevalence. Many of these pregnancies are resolved through unsafe abortion. Unsafe abortion constitutes a huge burden to women's health and reproductive lives especially in Nigeria where it is perceived illegal. The media plays a significant part in shaping public perceptions of health issues, and abortion attracts continued media interest. The objective of this research was to explore the context of abortion stigma on campus using University of Benin as a reference point, through qualitative and quantitative research at baseline/ endline. In achieving this, related youth concerns on the campus that fuels unplanned pregnancy and unsafe abortion such as rape, none use of contraception, drug abuse and cultism were equally assessed to determine the level of stigmatization placed on perceived offenders. Findings were used to develop an intervention strategy on stigmatizing attitudes and beliefs about abortion. Following airing of 24 episodes radio drama on abortion and related concerns, findings were scored and interpreted using the Stigmatizing Attitudes, Beliefs and Actions Scale (SABAS). Our findings showed significant decrease in the negative dimensions and improvement in positive discuss of abortion following increased awareness and education on abortion and related concerns.
\end{abstract}

Keywords Abortion, Abortion Stigma, Stigma Score, Radio

\section{Introduction}

Meriam Webster defined abortion as the termination of a pregnancy after, accompanied by, resulting in, or closely followed by the death of the embryo or foetus [1]. In Nigeria, abortion is legally restricted, permitted only to save the life of the mother [2]. Abortion in Nigeria is governed by two laws that differ depending on geographical location. Northern Nigeria is governed by the Penal Code and Southern Nigeria is governed by the Criminal Code.

Since abortion is illegal in Nigeria, many women resort to unsafe abortion methods, leading to abortion-related complications and increasing morbidity and mortality rates in the country. According to research done by the Guttmacher Institute, an estimated 456,000 unsafe abortions are done in Nigeria every year [3]. In a joint study carried out by the Society of Gynaecologists and Obstetricians of Nigeria and Nigeria's Ministry of Health, estimates of women who engage in unsafe abortion were put at about 20,000 each year [4]. Research has revealed that only $40 \%$ of abortions are performed by physicians with improved health facilities while the remaining percentage is performed by non-physicians [5].

Unwanted pregnancy is the leading cause for abortion in Nigeria [6]. Nigeria has one of the highest maternal mortality ratios in the world [7]. Although the government has acknowledged the problem and committed to improving maternal health, evidence suggests that progress has been limited, and unsafe abortion remains a major contributor to maternal morbidity and mortality.

The World Health Organization estimates that $97 \%$ of abortion procedures in Africa are performed unsafely [8], either by an unskilled provider, with inadequate methods or in an unhygienic environment. The poor practice of a safe and common medical procedure results in the death of more than 26,000 African women each year [8,9]. Most deaths occur where abortion laws are highly restrictive, but they also occur in less restrictive environments.

Abortion stigma is the discrediting of individuals as a result of their association with abortion [10]. The individuals include women who have had abortions, individuals who work in facilities that provide abortion, and supporters of women who have had abortions, including partners, family, and friends, as well as abortion researchers and advocates. Its impact on women's health 
and well-being is grave most especially in the developing countries with restrictive abortion laws. Abortion stigma plays a significant role in women's decision on whether to have a safe or unsafe abortion. It can lead women to seek unsafe abortions clandestinely to avoid judgment by society or contribute to women avoiding or delaying safe post abortion care [11]. Understanding abortion stigma is, therefore, essential to inform strategies to reduce it and, thus, has direct implications for improving access to care and better health for those whom stigma affects.[10]

The media plays a significant role in shaping public perceptions and opinions as evidenced by several studies that explored the role of the media in reducing HIV and AIDS stigma. The media can therefore, be leveraged to address popular and similar themes like abortion stigma. More so, a 2015 study on the digital habits and preferences of Nigerian youth aged 10-25 revealed that young people are media savvy and dependent - rely almost exclusively on TV, radio, online and social media channels for almost all forms of information, including sexual and reproductive health. Another study found that over 92\% of undergraduates at the University of Benin reported listening to UNIBEN FM 100.1 radio daily.

These studies, underscores the importance of designing and testing innovative media-based approaches to target and engage young undergraduates in efforts to address and reduce stigma and ultimately, increase access to quality, unbiased safe abortion services.

\section{Methods}

The study was conducted in University of Benin (UNIBEN), Edo state. It is a federal government tertiary institution located in Benin City, Edo state, South-South geopolitical zone in Nigeria. University of Benin (UNIBEN) offers courses and programs leading to bachelor degrees, master degrees, doctorate degrees in several areas of study. UNIBEN offers a diverse range of courses of study, which includes Theatre Arts, Mass Communication, Natural sciences, Medicine, Engineering, Management Science, Social Science, Law, Education, African and European Languages. UNIBEN has functional ultra-model FM radio station (FM 100.1, Golden station) transmitting news within the campus.

The study was targeted to those who have the capacity to understand audio drama as against those watching television because of the high cost of production and airing and the desire for replication at minimum cost. Therefore, the choice of the audience was purposive

The study employed a cross-sectional descriptive study design, using self-administered questionnaires. Multi-stage sampling technique was used to select 400 undergraduate students from all levels of undergraduates study in the faculties at the university's campus in Benin City. The study participants were full time students drawn from the total population of forty two thousand, six hundred $(42,600)$ during the 2015/2016 academic year who voluntarily took part in qualitative focus group discussions and quantitative survey.

The study instrument was a pre-tested semi structured questionnaire which was developed using the Ipas Stigmatizing Attitudes, Beliefs and Actions Scale (SABAS) tool designed to measure abortion stigma at the individual and university community level. SABAS captures three important dimensions of abortion stigma: negative stereotypes about men and women who are associated with abortion, discrimination/exclusion of women who have abortions, and fear of contagion as a result of coming in contact with a woman who has had an abortion. The tool was used at baseline and end line data collection. The tool which was a 71-item survey instrument was created from several variables covering the following; rape -10 , abortion -16 , unplanned pregnancies -15 , cultism -10 , substance abuse- 10 and contraception -10 . This was pre-tested, retested and then administered to 400 undergraduates.

A total of 16 (8-females, 8-males) Focus Group Discussions [FGD] developed from the Ipas FGD SABAS qualitative tool, were conducted amongst undergraduates' at all levels in the university to provide information around stigmatization and criminalization related to abortion, contraceptive usage, cultism, unplanned pregnancy, rape and substance abuse

The response categories for SABAS were set up on a Likert scale from "strongly disagree" to "strongly agree" with each response being assigned a value ranging from 1-5. The SABAS was scored in four different ways: total score, negative stereotyping subscale, exclusion and discrimination subscale, and fear of contagion subscale. (Please note that all question items attract reverse coding and a higher score reflects a more stigmatizing attitude, i.e. strongly disagree $=1$, disagree $=2$, unsure $=3$, agree $=4$ and strongly agree=5.). Regardless of whether it is the total SABAS score or the score of individual sub-scales, a higher score represents more stigmatizing attitudes and beliefs about women who have an abortion. In the context of this study, a predetermined cut-offs or a threshold of 2.5 was set as acceptable positive attitude or stigma level [threshold]. Higher than 2.5 is high stigma and lower is low stigma.

Data from the questionnaires were entered into the SPSS Version 16 statistical software, which was used in performing all the analysis. Frequency tables and cross-tabulations were computed. Chi-square analysis was used to test for associations between knowledge and attitude towards abortion and other youth concerns in the institution. The level of statistical significance was based on a p-value level of less than 0.05 .

Following approval from the university authority, the purpose of the study was explained to the participating students and confidentiality was assured due to the sensitive nature of the subject. Informed consent was 
obtained from every student before giving out the questionnaire. They were assured of the anonymity of their identity and the confidentiality of their responses. Participants were assured that participation in the study was voluntary and they were free to withdraw at any point in the study.

Value Clarification and Attitudinal Transformation (VCAT) exercise was conducted in the engagement of a consultant to develop a 24 week drama scripts series addressing emerging themes from the baseline survey, audition and cast. IEC materials such as posters, stickers and fliers were developed and distributed within the campus to popularise the campus radio drama series. A Listeners Club (LC) was established to monitor, criticize and harness feedback from the airing. The club members were briefed on how to analyze the scripts and send feed back to the project team for the purpose of improving on subsequent productions. Questions on what is liked, disliked \& how to improve drama series were part of the brief.

Following the 24weeks of airing and the continuous activities of the listeners club aimed at educating the campus community on the dangers of stigma, an endline qualitative and quantitative survey was conducted to determine changes if any in the dimensions of abortion stigma.

\section{Results}

\subsection{Main Characteristics of Respondents}

A total of 400 respondents took part in this survey. Three hundred out of the four hundred questionnaires administered were retrieved and analyzed, representing a response rate of $75 \%$. Eight faculties participated in the survey namely Arts, Social Sciences, Education, Humanities, Medicine, Pharmacy, Agriculture and Law. A little more than half (51\%) of the students surveyed are in 300 level, followed by one third (33.3\%) in 400 level while the least represented were in 100 level. The marital status revealed that there are more singles $(80 \%)$ respondents than the married.

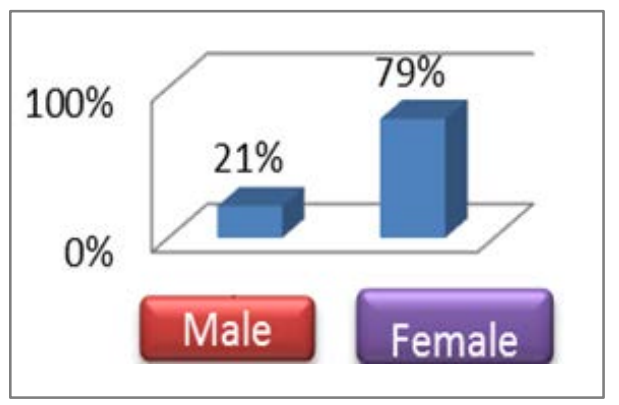

Figure 1. Sex

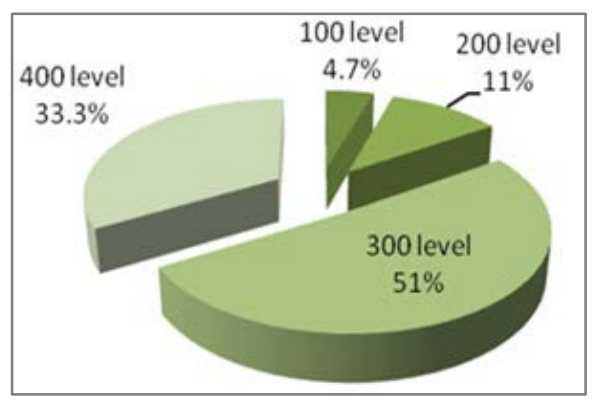

Figure 2. Academic level

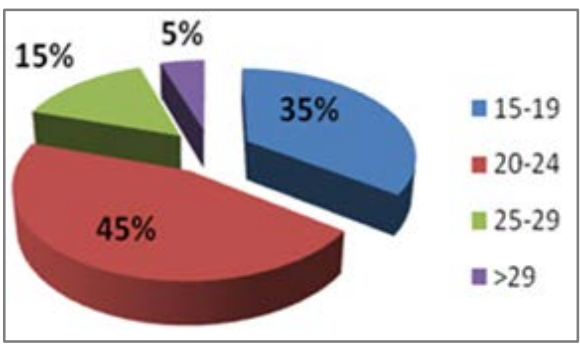

Figure 3. Age strate of respondents

\subsection{Description of Results}

The study utilized the Ipas Stigmatizing Attitudes, Beliefs, and Actions Scale (SABAS) quantitative survey tool to capture three important dimensions of abortion stigma: [1] negative stereotypes about undergraduates who are associated with abortion, [2] discrimination/ exclusion of undergraduates females who have abortions, and [3] fear of contagion as a result of coming in contact with an undergraduate female who has had an abortion.

On stigma related to negative stereotypes; the 8-item SABAS tool showed high negative stereotypes about undergraduates who are associated with abortion. Almost all question items had a score higher than the abortion stigma threshold of 2.51. More than two-third 66.7\% believed any woman who have committed abortion committed sin (Stigma Score $=3.97$ ); while more than a quarter $(41 \%, \mathrm{SC}=3.03)$ hold strong view that students that had abortion will encourage others to do same. Participants disagreed $(54 \%, \mathrm{SC}=2.30)$ that "A woman who commits abortion cannot be trusted" while a little less than a-third $(29 \%$, SC $=2.88)$ believed that anyone committing abortion brings shame to the family. On the belief that "The health of a woman committing abortion is never as healthy as it was before the abortion" more than a third $(34.7 \%$; SC $=3.43)$ agreed to the assertion while $(48 \%$; SC $=2.88)$ of the respondents disagreed with the fact that "a woman who had an abortion is a bad mother".

On abortion stigma related to discrimination and exclusion; findings showed a total of $60 \%$ (SC $=3.15$ ) of the respondents believed “A man shouldn't marry a woman who has had an abortion as she may not be able to bear children" though, majority $(87.7 \%, \mathrm{SC}=0.61)$ disagree that they would stop being friends with someone found to have had abortion. 
On fear of contagion as a result of coming in contact with an undergraduate female who has had an abortion, the study revealed that $42 \%(S C=2.78)$ of the respondents affirmed that a woman who has had abortion can 'contaminate' her friends.

Table 1. Attitude and stigma on abortion on campus (Negative stereotypes)

1. A woman who had committed abortion has sinned

2. Once a woman commit abortion it will become a habit

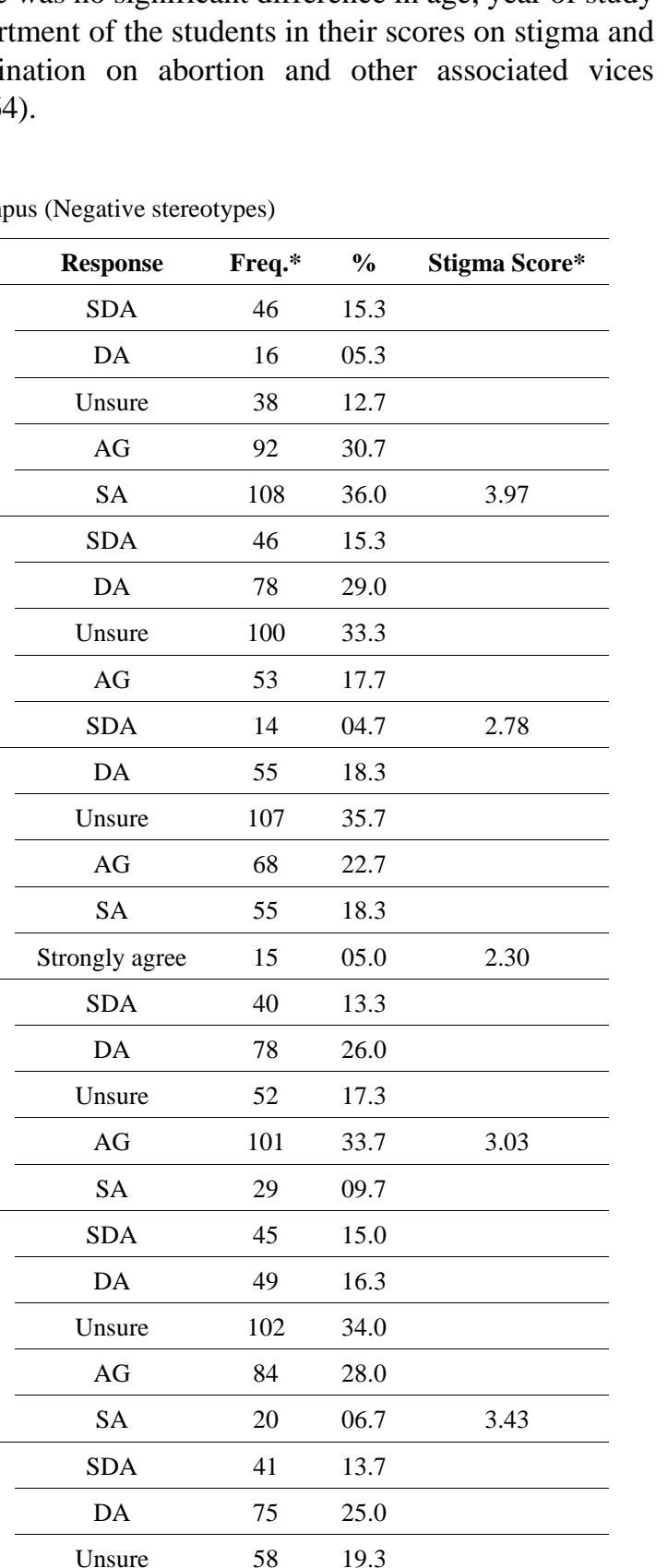

3. A woman who commit abortion cannot be trusted

4. Any one committing abortion is a shame to the family

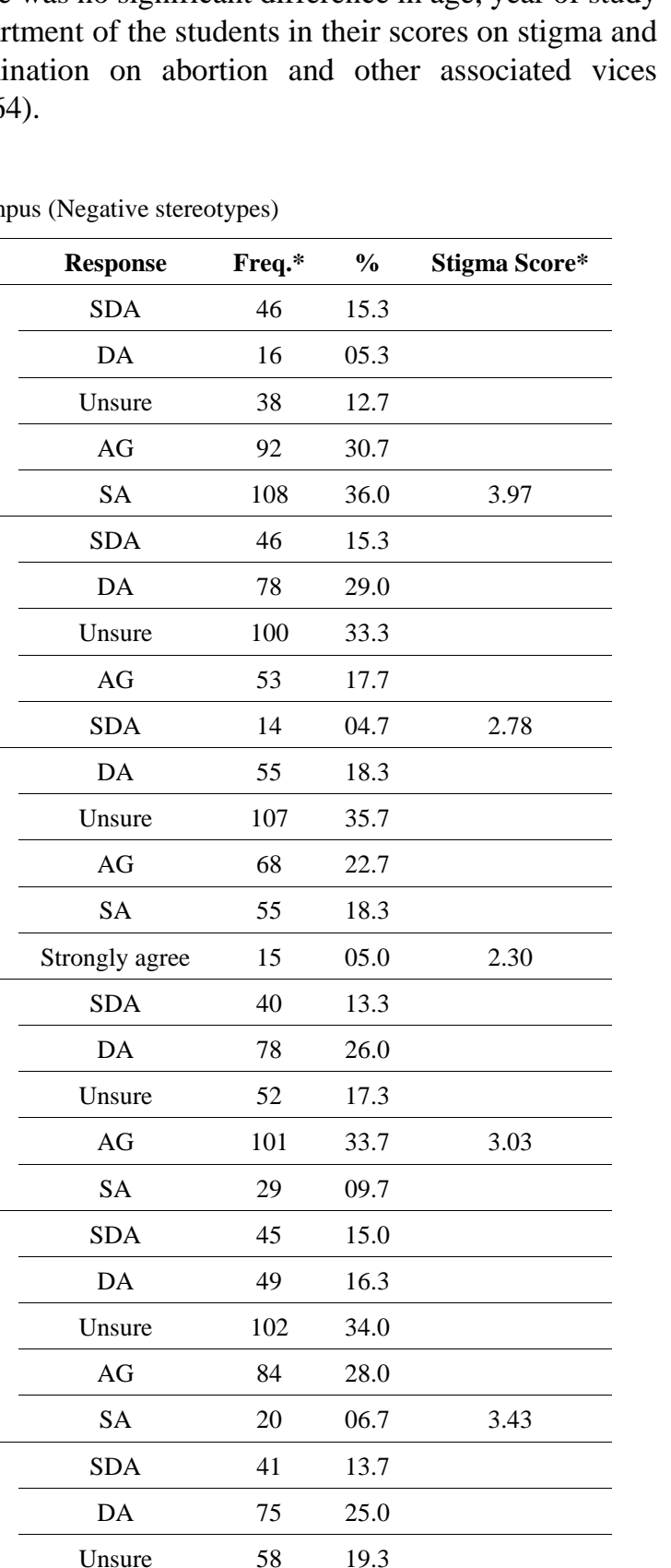

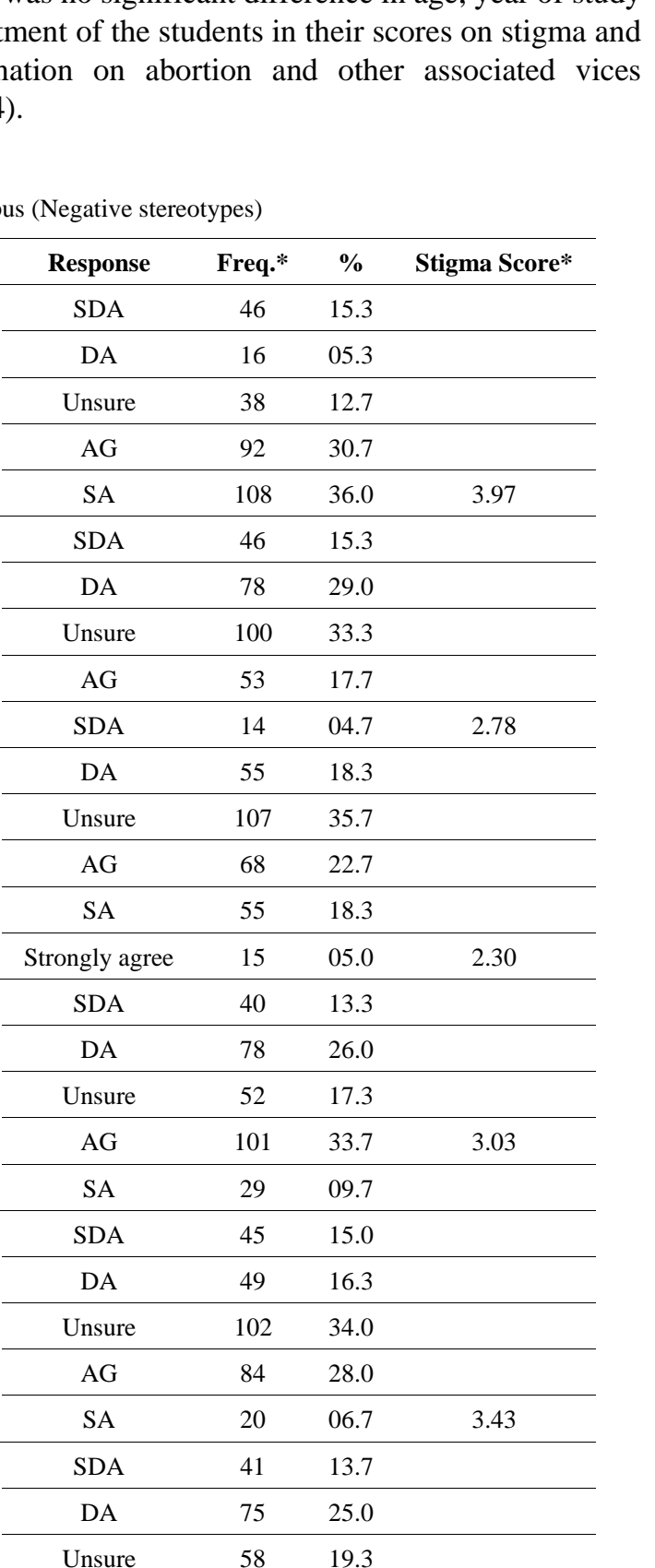

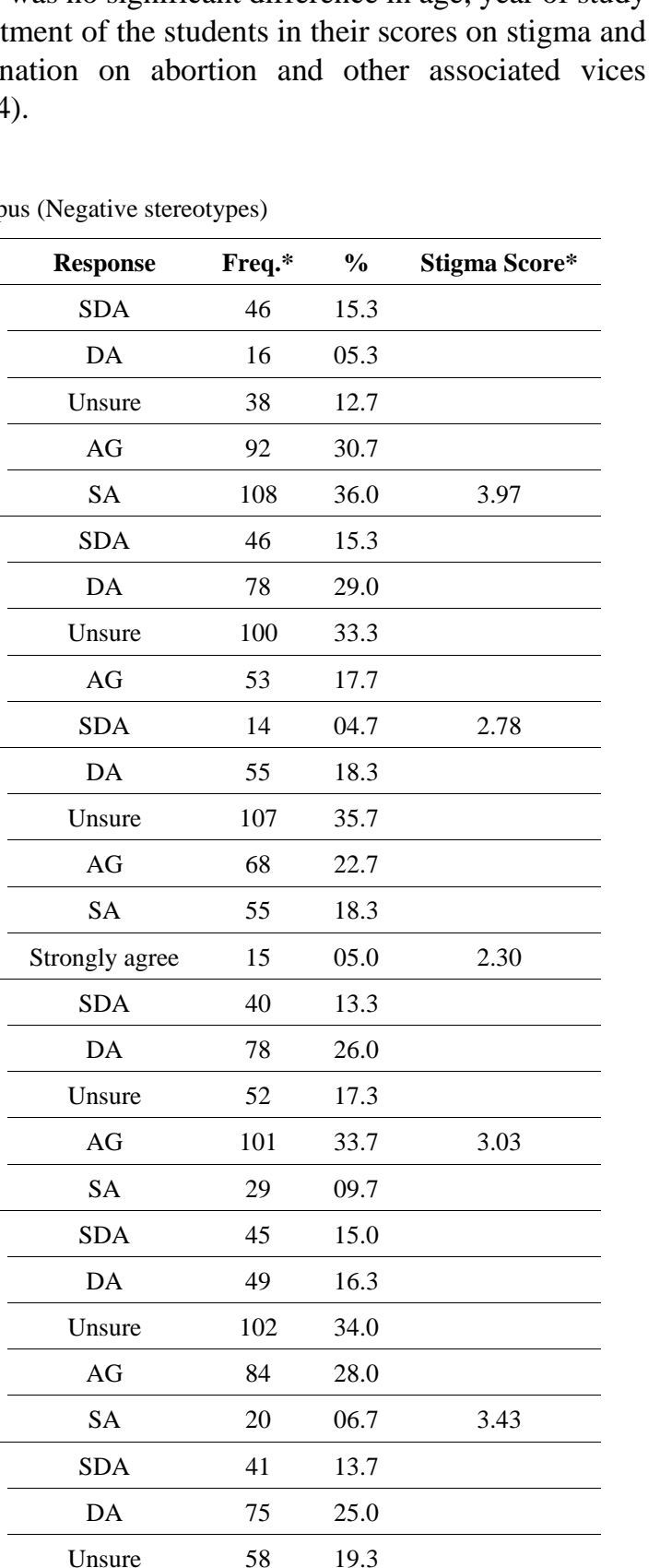

5. The health of a woman committing abortion is never healthy as before

6. Any woman committing abortion can encourage other women to do same

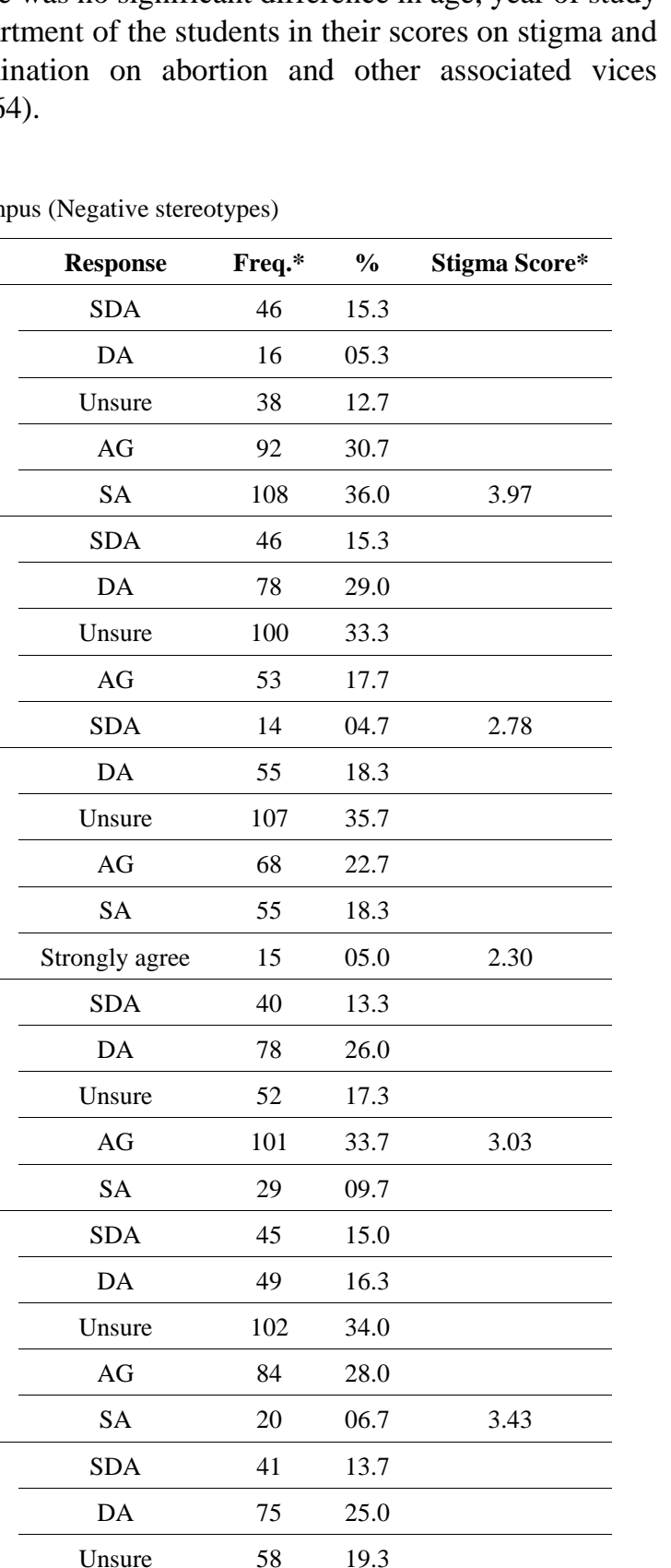
or departin discrimination $(\mathrm{p}=0.064)$.

(r)


Table 2. Attitude and stigma on abortion on campus (Discrimination/exclusions)

1. A woman who has had abortion should be prohibited from religious service

\begin{tabular}{|c|c|c|c|}
\hline Response & Freq. & $\%$ & $\begin{array}{l}\text { Stigma } \\
\text { Scores }\end{array}$ \\
\hline SDA & 128 & 42.7 & \\
\hline DA & 102 & 34.0 & \\
\hline Unsure & 45 & 15.0 & \\
\hline AG & 16 & 05.3 & \\
\hline SA & 09 & 03.0 & 1.16 \\
\hline SDA & 147 & 49.0 & \\
\hline DA & 112 & 37.3 & \\
\hline Unsure & 16 & 05.3 & \\
\hline$A G$ & 15 & 05.0 & \\
\hline SA & 10 & 3.3 & 0.68 \\
\hline SDA & 146 & 48.7 & \\
\hline DA & 118 & 39.3 & \\
\hline Unsure & 21 & 07.0 & \\
\hline$A G$ & 14 & 04.7 & \\
\hline SA & 01 & 0.30 & 0.60 \\
\hline SDA & 12 & 04.7 & \\
\hline DA & 102 & 34.0 & \\
\hline Unsure & 09 & 03.3 & \\
\hline AG & 122 & 40.7 & \\
\hline SA & 58 & 19.3 & 3.15 \\
\hline SDA & 134 & 44.7 & \\
\hline DA & 129 & 43.0 & \\
\hline Unsure & 25 & 8.3 & \\
\hline$A G$ & 06 & 02.0 & \\
\hline SA & 06 & 02.0 & 0.61 \\
\hline SDA & 11 & 03.7 & \\
\hline DA & 13 & 05.3 & \\
\hline Unsure & 137 & 45.3 & \\
\hline AG & 136 & 45.7 & \\
\hline SA & 03 & 01.0 & 4.60 \\
\hline
\end{tabular}

4. A man shouldn't marry a woman who had committed abortion as she may not be able to bear children

2. Teasing a woman who has had abortion would make her ashamed of her decision

3. I would disgrace a woman if found she has had abortion

5. I would stop friendship with someone found to have committed abortion

6. I will point finger at any woman who had committed abortion so other will know her

Table 3. Attitude and stigma on abortion on campus (contagion on abortion)

\begin{tabular}{|c|c|c|c|c|}
\hline & Responses & Freq* & $\%$ & S/Scores* \\
\hline \multirow{5}{*}{ 1. Any woman who had committed abortion can contaminate her friends } & Strongly disagree & 57 & 19.0 & \\
\hline & Disagree & 76 & 25.3 & \\
\hline & Unsure & 41 & 13.7 & \\
\hline & Agree & 73 & 24.3 & \\
\hline & Strongly agree & 53 & 17.7 & 2.78 \\
\hline \multirow{5}{*}{$\begin{array}{l}\text { 2. If a man had sexual intercourse with a woman who had committed abortion he } \\
\text { will be infected with disease }\end{array}$} & Strongly disagree & 146 & 48.7 & \\
\hline & Disagree & 89 & 29.7 & \\
\hline & Unsure & 49 & 16.3 & \\
\hline & Agree & 14 & 04.7 & \\
\hline & Strongly agree & 02 & 0.70 & 1.08 \\
\hline
\end{tabular}




\subsubsection{Focus Group Discussions (FGD)}

A total of 11 departments/courses selected from all level of studies participated in the 16 FGDs (8 males, 8 females) conducted. Discussion generated information on unplanned pregnancy, contraceptive usage by female undergraduates, abortion, rape and cultism on campuses. On why women experience unplanned pregnancies; opinions range from ignorance, lack of knowledge on 'safe period' non-use of contraceptives, fear of use of contraceptives as unmarried students and peer pressure to belong to 'big girls' on campus. A 200 level student of Mass Communication stated that the reason behind unwanted pregnancy is lack of exposure. This is because most teenagers were locked up for too long at home and for that reason, a little minute outside they will want to explore the world. Another 300 level student of Mass Communication also supported this motion by adding that ignorance of what pregnancy is all about also affects them. Other views expressed include students using not reliable "Withdrawal method" that's why they end up getting pregnant when they are not ready. Students unanimously agreed that unmarried students who experienced unplanned pregnancy are usually stigmatized and discriminated against in many ways. A 100 level social science student responded that people neglect the pregnant lady not minding the cause. Another Science female student stated that friends and family do no longer care about them and as such their status/ego in the society drops as well as members of his family classifying them as bad eggs and as such leaving them with little or no support. A female final year student responded that the school react too negative about unwanted pregnancy as even members of staff tends to even ridicule the victim among other peers. Many share the view that both the parents and the girl are blamed by the society

Participants for the FGD stated that the failure or non-use of contraception result to either unplanned pregnancy or abortion. The general opinion of discussants was that students do not use contraception and the few that use are adjudged to be 'loose', 'prostitutes', and 'wayward'. Participants unanimously agreed that the only contraception known on campus is condom.

Abortion as an issue generated a lot of discussions which were rather very passionate among female discussants. Most female discussants were more vehement than their male groups; maybe due to the fact that they suffer the stigma resulting from abortion. Most discussants corroborated the survey findings that most Nigerians see abortion as an abomination and would abuse and point accused fingers at the girl who committed an abortion. Half of the FGD discussants agreed that many people support abortion when it relates to their loved ones impregnated by less fancied persons but they may not say it out loud except to those close to them. To some discussants if a student commit abortion on campus friends will no longer associates with her, many will chase her, discriminate against her on certain relationships including campus fellowship. Also, because they believe associating with her would bring them shame, a male discussant stated that pregnancy is pregnancy whether under rape or consensual and abortion is abortion whether as a result of rape or not. However, the female FGDs were of different views. According to them, as a rape victim the society will empathize with her compare to the person who got pregnant out of deliberate intercourse who will be left to suffer the shame and isolation alone. They were of the opinion that a rape victim is justified when she aborts the baby but one that had consensual intercourse that result in pregnancy will never receive sympathy. For the female FGD discussants, being raped alone carry a heavy stigma coupled with getting pregnant out of it; and can be one of the worse scenarios on campus as it carries double stigmatization. 
Table 4. Perception of Students on unplanned pregnancy

\begin{tabular}{|c|c|c|c|}
\hline & Response & Frequency* & Percentage \\
\hline \multirow{7}{*}{ Any pregnant student that is unmarried has sinned } & Strongly & 41 & 13.6 \\
\hline & disagree & & \\
\hline & Disagree & 72 & 24.0 \\
\hline & Unsure & 38 & 12.7 \\
\hline & Agree & 114 & 38.0 \\
\hline & Strongly & 35 & 11.7 \\
\hline & agree & & \\
\hline \multirow{7}{*}{ A pregnant unmarried student will likely repeat the act outside wedlock } & Strongly & 51 & 17.0 \\
\hline & disagree & & \\
\hline & Disagree & 102 & 34.0 \\
\hline & Unsure & 62 & 20.7 \\
\hline & Agree & 67 & 22.3 \\
\hline & Strongly & 18 & 06.0 \\
\hline & agree & & \\
\hline \multirow{7}{*}{ An unmarried pregnant student can't be morally trusted } & Strongly & 78 & 26.0 \\
\hline & disagree & & \\
\hline & Disagree & 113 & 37.7 \\
\hline & Unsure & 48 & 16.0 \\
\hline & Agree & 51 & 17.0 \\
\hline & Strongly & 10 & 03.3 \\
\hline & agree & & \\
\hline \multirow{7}{*}{ A pregnant unmarried student brings shame to the family } & Strongly & 25 & 08.3 \\
\hline & disagree & & \\
\hline & Disagree & 51 & 17.0 \\
\hline & Unsure & 33 & 11.0 \\
\hline & Agree & 170 & 56.7 \\
\hline & Strongly & 21 & 07.0 \\
\hline & agree & & \\
\hline \multirow{7}{*}{$\begin{array}{l}\text { The self-esteem of an unmarried pregnant student can never be as good } \\
\text { as it was. }\end{array}$} & Strongly & 32 & 10.7 \\
\hline & disagree & & \\
\hline & Disagree & 62 & 20.7 \\
\hline & Unsure & 41 & 13.6 \\
\hline & Agree & 132 & 44.0 \\
\hline & Strongly & 33 & 11.0 \\
\hline & agree & & \\
\hline \multirow{7}{*}{ An unmarried pregnant student will be a bad influence to others } & Strongly & 86 & 28.7 \\
\hline & disagree & & \\
\hline & Disagree & 126 & 42.0 \\
\hline & Unsure & 44 & 14.7 \\
\hline & Agree & 31 & 10.3 \\
\hline & Strongly & 13 & 04.3 \\
\hline & agree & & \\
\hline \multirow{7}{*}{ An unmarried pregnant student is a bad mother to the child } & Strongly & 121 & 40.4 \\
\hline & disagree & & \\
\hline & Disagree & 123 & 41.0 \\
\hline & Unsure & 36 & 12.0 \\
\hline & Agree & 10 & 03.3 \\
\hline & Strongly & 10 & 03.3 \\
\hline & agree & & \\
\hline
\end{tabular}


Table 5. Perception on Rape

A raped woman dignity is been destroyed

\begin{tabular}{|c|c|c|}
\hline Response & Freq* & $\%$ \\
\hline Strongly disagree & 167 & 55.7 \\
\hline Disagree & 115 & 38.3 \\
\hline Unsure & 09 & 03.0 \\
\hline Agree & 04 & 01.3 \\
\hline Strongly agree & 05 & 01.7 \\
\hline Strongly disagree & 81 & 27.0 \\
\hline Disagree & 136 & 45.3 \\
\hline Unsure & 36 & 12.0 \\
\hline Agree & 33 & 11.0 \\
\hline Strongly agree & 14 & 04.7 \\
\hline Strongly disagree & 59 & 19.7 \\
\hline Disagree & 94 & 31.3 \\
\hline Unsure & 32 & 10.7 \\
\hline Agree & 87 & 29.0 \\
\hline Strongly agree & 28 & 09.3 \\
\hline Strongly disagree & 132 & 44.0 \\
\hline Disagree & 130 & 43.3 \\
\hline Unsure & 23 & 07.7 \\
\hline Agree & 09 & 03.0 \\
\hline Strongly agree & 06 & 02.0 \\
\hline Strongly disagree & 132 & 44.0 \\
\hline Disagree & 108 & 36.0 \\
\hline Unsure & 20 & 06.7 \\
\hline Agree & 34 & 11.3 \\
\hline Strongly agree & 06 & 02.0 \\
\hline Strongly disagree & 51 & 17.0 \\
\hline Disagree & 50 & 16.7 \\
\hline Unsure & 34 & 11.3 \\
\hline Agree & 136 & 45.3 \\
\hline Strongly agree & 29 & 09.7 \\
\hline Strongly disagree & 199 & 66.3 \\
\hline Disagree & 70 & 23.3 \\
\hline Unsure & 11 & 03.7 \\
\hline Agree & 11 & 03.7 \\
\hline Strongly agree & 09 & 03.0 \\
\hline Strongly disagree & 234 & 78.0 \\
\hline Disagree & 55 & 18.3 \\
\hline Unsure & 01 & 0.30 \\
\hline Agree & 05 & 01.7 \\
\hline Strongly agree & 05 & 01.7 \\
\hline Strongly disagree & 162 & 54.0 \\
\hline Disagree & 63 & 21.0 \\
\hline Unsure & 46 & 15.3 \\
\hline Agree & 21 & 07.0 \\
\hline Strongly agree & 08 & 02.7 \\
\hline Strongly disagree & 183 & 61.0 \\
\hline Disagree & 91 & 30.3 \\
\hline Unsure & 11 & 03.7 \\
\hline Agree & 13 & 04.3 \\
\hline Strongly agree & 02 & 0.70 \\
\hline
\end{tabular}


Table 6. Perception of students on cultism on campus

\begin{tabular}{|c|c|c|c|}
\hline & Response & Frequency & Percentage \\
\hline \multirow{5}{*}{ Cultist shouldn't be counselled but rusticated } & SDA & 82 & 27.3 \\
\hline & DA & 87 & 29.0 \\
\hline & Unsure & 36 & 12.0 \\
\hline & AG & 48 & 16.0 \\
\hline & SA & 47 & 15.7 \\
\hline \multirow{5}{*}{ Student cultist are not fit to be among human beings } & SDA & 84 & 28.0 \\
\hline & DA & 106 & 35.3 \\
\hline & Unsure & 42 & 14.0 \\
\hline & $\mathrm{AG}$ & 53 & 17.7 \\
\hline & SA & 15 & 05.0 \\
\hline \multirow{5}{*}{ A student cultist cannot be trusted } & SDA & 23 & 07.7 \\
\hline & DA & 52 & 17.3 \\
\hline & Unsure & 46 & 15.3 \\
\hline & AG & 130 & 43.3 \\
\hline & SA & 49 & 16.4 \\
\hline \multirow{5}{*}{ A student cultist is a shame to the family } & SDA & 23 & 07.7 \\
\hline & DA & 48 & 16.0 \\
\hline & Unsure & 44 & 14.7 \\
\hline & $\mathrm{AG}$ & 124 & 41.3 \\
\hline & SA & 61 & 20.3 \\
\hline \multirow{5}{*}{$\begin{array}{l}\text { Punishment for cultist should not be flexible even when they } \\
\text { renounced }\end{array}$} & SDA & 43 & 14.3 \\
\hline & DA & 73 & 24.3 \\
\hline & Unsure & 73 & 24.3 \\
\hline & $\mathrm{AG}$ & 74 & 24.7 \\
\hline & SA & 37 & 12.3 \\
\hline \multirow{5}{*}{ Once a cultist always a cultist, no repentant cultist } & SDA & 98 & 32.7 \\
\hline & DA & 122 & 40.7 \\
\hline & Unsure & 37 & 12.3 \\
\hline & AG & 24 & 08.0 \\
\hline & SA & 19 & 06.3 \\
\hline \multirow{5}{*}{$\begin{array}{l}\text { A cultist should be treated same way as student that need } \\
\text { counselling }\end{array}$} & SDA & 40 & 13.3 \\
\hline & DA & 58 & 19.3 \\
\hline & Unsure & 33 & 11.0 \\
\hline & $\mathrm{AG}$ & 130 & 43.4 \\
\hline & SA & 39 & 13.0 \\
\hline \multirow{5}{*}{ I will disgrace any known cultist if I have the opportunity } & SDA & 80 & 26.7 \\
\hline & DA & 107 & 35.7 \\
\hline & Unsure & 50 & 16.6 \\
\hline & $\mathrm{AG}$ & 33 & 11.0 \\
\hline & SA & 30 & 10.0 \\
\hline
\end{tabular}

$\mathrm{N}=300$ 
Table 7. Perception of students on contraceptive usage

An unmarried student using family planning method is bad

Student using family planning method are loosed and immoral

Student using FP are morally bankrupt compared to others

\begin{tabular}{c} 
Response \\
\hline Strongly disagree \\
\hline Disagree \\
\hline Unsure \\
\hline Agree \\
\hline Strongly agree \\
\hline Strongly disagree \\
\hline Disagree \\
\hline Unsure \\
\hline Agree
\end{tabular}

Frequency

Percentage

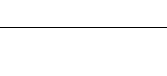

Student using family planning is committing sin

Girls prefer using the condom in other to prevent HIV

I will disassociate from a female colleague using FP method

Students using contraceptives have something to hide

\begin{tabular}{cll}
\hline Strongly agree & 34 & 11.3 \\
\hline Strongly disagree & 96 & 32.0 \\
\hline Disagree & 82 & 27.3 \\
\hline Unsure & 78 & 26.0 \\
\hline Agree & 35 & 11.7 \\
\hline Strongly agree & 09 & 03.0 \\
\hline Strongly disagree & 59 & 19.7 \\
\hline Disagree & 70 & 23.3 \\
\hline Unsure & 60 & 20.0 \\
\hline Agree & 84 & 28.0 \\
\hline Strongly agree & 27 & 09.0
\end{tabular}

$\longrightarrow$

\begin{tabular}{ccc} 
Strongly disagree & 111 & 37.0 \\
\hline Disagree & 74 & 24.7 \\
\hline Unsure & 52 & 17.3 \\
\hline Agree & 56 & 18.7 \\
\hline Strongly agree & 07 & 02.3
\end{tabular}

\begin{tabular}{ccc} 
Strongly disagree & 147 & 49.0 \\
\hline Disagree & 101 & 33.7 \\
\hline Unsure & 17 & 05.7 \\
\hline Agree & 26 & 08.7 \\
\hline
\end{tabular}

\begin{tabular}{ccc}
\hline Strongly agree & 09 & 08.7 \\
\hline Strongly disagree & 61 & 03.0 \\
\hline Disagree & 79 & 20.3 \\
\hline Unsure & 68 & 26.3 \\
\hline Agree & 72 & 22.7 \\
\hline
\end{tabular}

$\begin{array}{ccc}72 & 24.0 \\ \text { Strongly agree } & 20 & 06.7\end{array}$

\begin{tabular}{cll} 
Strongly disagree & 80 & 26.7 \\
\hline Disagree & 89 & 29.7 \\
\hline Unsure & 58 & 19.3 \\
\hline Agree & 48 & 16.0 \\
\hline Strongly agree & 25 & 08.3
\end{tabular}

Parent encouraging their daughter to using FP is a bad parent

An unmarried student using contraceptive method need deliverance

Intimate association with a girl that uses FP will be scaring

\begin{tabular}{ccc} 
Strongly disagree & 109 & 36.3 \\
\hline Disagree & 104 & 34.7 \\
\hline Unsure & 46 & 15.3 \\
\hline Agree & 30 & 10.0 \\
\hline Strongly agree & 11 & 03.7 \\
\hline Strongly disagree & 119 & 39.9 \\
\hline Disagree & 109 & 36.3 \\
\hline Unsure & 24 & 08.0 \\
\hline Agree & 34 & 11.3 \\
\hline Strongly Agree & 14 & 0.47
\end{tabular}


Table 8. Perception of students on substance abuse

\begin{tabular}{|c|c|c|c|}
\hline & Response & Frequency* & Percentage \\
\hline \multirow{5}{*}{ To consume alcohol and dangerous drugs is sinful } & SDA & 43 & 14.3 \\
\hline & DA & 43 & 14.3 \\
\hline & Unsure & 38 & 12.7 \\
\hline & $\mathrm{AG}$ & 118 & 39.4 \\
\hline & SA & 58 & 19.3 \\
\hline \multirow{5}{*}{ A student who consume alcohol and dangerous drugs will make it a habit } & SDA & 27 & 09.0 \\
\hline & DA & 30 & 10.0 \\
\hline & Unsure & 29 & 09.7 \\
\hline & AG & 144 & 48.0 \\
\hline & SA & 70 & 23.3 \\
\hline \multirow{5}{*}{ A student alcoholic cannot be trusted } & SDA & 34 & 11.3 \\
\hline & DA & 48 & 16.0 \\
\hline & Unsure & 78 & 26.0 \\
\hline & AG & 103 & 34.3 \\
\hline & SA & 37 & 12.3 \\
\hline \multirow{5}{*}{ A student alcoholic or drug addict bring shame to the family } & SDA & 21 & 07.0 \\
\hline & DA & 33 & 11.0 \\
\hline & Unsure & 68 & 22.7 \\
\hline & $\mathrm{AG}$ & 130 & 43.3 \\
\hline & SA & 48 & 16.0 \\
\hline \multirow{5}{*}{ A student alcoholic and drug taker is always sick compare to his colleague don't } & SDA & 37 & 12.3 \\
\hline & DA & 65 & 21.7 \\
\hline & Unsure & 90 & 30.0 \\
\hline & AG & 77 & 25.7 \\
\hline & SA & 31 & 10.3 \\
\hline \multirow{5}{*}{ A student who consume alcohol and drugs might encourage his colleague } & SDA & 40 & 13.3 \\
\hline & DA & 31 & 10.3 \\
\hline & Unsure & 51 & 17.0 \\
\hline & AG & 127 & 42.3 \\
\hline & SA & 51 & 17.0 \\
\hline \multirow{5}{*}{ A student who consume alcohol and drugs should be rusticated from campus } & SDA & 42 & 14.0 \\
\hline & DA & 93 & 31.0 \\
\hline & Unsure & 73 & 24.3 \\
\hline & AG & 64 & 21.3 \\
\hline & SA & 28 & 09.3 \\
\hline \multirow{5}{*}{ Alcohol and hard drug consumers should be treated equally and punished } & SDA & 45 & 15.0 \\
\hline & DA & 52 & 17.3 \\
\hline & Unsure & 91 & 30.3 \\
\hline & AG & 89 & 29.7 \\
\hline & SA & 23 & 07.7 \\
\hline
\end{tabular}

$* \mathrm{~N}=300$

The Ipas Stigmatizing Attitudes, Beliefs, And Actions Scale (SABAS) tool was used at endline survey after 20 weeks of radio drama series airing and activities of listeners' club. Findings showed a significant decrease in the dimensions of abortion issues. FGD findings also showed improvement in positive discuss on abortion issues. 
Table 9. Comparative stigma scores at baseline and endline survey

\begin{tabular}{lccc}
\hline \multicolumn{1}{c}{ ITEMS* } & $\begin{array}{c}\text { SCORES AT } \\
\text { BASELINE }\end{array}$ & $\begin{array}{c}\text { SCORES AT } \\
\text { ENDLINE }\end{array}$ & INFERENCE \\
\hline Once a woman commit abortion it will become a habit & 3.97 & 3.97 & REDUCED \\
\hline A woman who had committed abortion has sinned & 3.06 & 1.98 & REDUCED \\
\hline A woman committing abortion is a bad mother & 2.30 & 2.00 & REDUCED \\
\hline Any one committing abortion is a shame to the family & 3.15 & 1.20 & REDUCED \\
\hline $\begin{array}{l}\text { A man shouldn't marry a woman who had committed abortion as she } \\
\text { may not be able to bear children }\end{array}$ & 4.60 & 0.55 & REDUCED \\
\hline $\begin{array}{l}\text { I will point finger at any woman who had committed abortion so other } \\
\text { will know her }\end{array}$ & 2.78 & 1.88 & REDUCED \\
\hline Any woman who had committed abortion can contaminate her friends
\end{tabular}

*N=300; *Stigma interpretation: Scores of 0.10-2.50 = Positive attitude (no stigma); Scores of 2.51-5.00 Negative attitudes (stigma present)

\section{Discussion}

The findings of this survey have revealed high negative stereotypes about undergraduates who are associated with abortion. These findings agreed with several researches where abortion is illegal. WHO, 2015 reported that in countries where abortion is illegal, practitioners exhibit stigma and discrimination. Findings showed that practitioners resort to clandestine abortion practices because of fear of being arrested or branded [12] Almost all question items had a score higher than the abortion stigma threshold of 2.51. More than two-third $66.7 \%$ believed any woman who have committed abortion committed sin (Stigma Score SC $=3.97)$; while more than a quarter $(41 \%$, $\mathrm{SC}=3.03$ ) hold strong view that students that have had abortion will encourage others to do same. The FGD conducted amongst female students revealed that most victims would prefer to keep the abortion story secret, even if she has complications for fear of stigmatization and or branding.

There is huge implication in labelling women that perform abortion. A research amongst undergraduates in University of Nigeria, Nsukka, Nigeria showed that students were aware of the risks associated with unsafe abortion; however, the abortion rate was still high because the fear of being labelled makes them to seek abortion in hidden places even when they are not safe [13]. On the belief that "The health of a woman committing abortion is never as healthy as it was before the abortion” more than a third $(34.7 \%$; SC $=3.43)$ agreed to the assertion while $(48 \%$; SC $=2.88)$ of the respondents disagreed with the fact that "a woman who had an abortion is a bad mother".

On discrimination and exclusion of students who have had an abortion findings revealed that most students will not exclude a female who commits abortion. Most respondents, $76.7 \%$; $(\mathrm{SC}=1.16)$ believed that "a woman who has had abortion should not be prohibited from going to religious service”. In the same vein, $86.3 \%$ ( $\mathrm{SC}=0.68$ ) would not tease a woman who has had an abortion, to make her ashamed about her decision, but some $46.7 \%$ will point finger at an abortionist, while $45.3 \%$ are not sure of their decision $(\mathrm{SC}=4.60)$. On the flip side, $88 \%(\mathrm{SC}=0.60)$ of the respondents would not disgrace a woman in their community, if found to have had an abortion

The radio was cited by few discussants during FGDs as a source of information on campus thus emphasizing the importance of creating awareness and increasing radio listenership in the university. This is in agreement with the end line stigma scores of this survey, which showed a marked reduction following airing of the radio drama scripts on stigmatisation. These findings has shown that radio is a powerful instrument in the area of public enlightenment, on health issues, family planning, cultural re-awakening, business improvement and other social development issues [14]. This is, however, not different from findings from a review of literature on students use of the radio for information where $65 \%$ of students where campus radio exist rely on radio for information and academic instructions [15]. The National Universities Commission (NUC) also reported that students in Federal University of Technology Minna, Nigeria obtained academic and social information from the campus radio [16].

The study targeted undergraduate students with the hope that whatever stigma level is measured will explain how bad it will be at the grass root where radio is not free to listen to same drama. The qualitative and quantitative findings have further proved this assumption. 


\section{Recommendations}

- $\quad$ Nigerians current abortion laws should be reviewed to accommodate abortion that occurs due to incest and rape.

- $\quad$ Further research is needed for each of the thematic areas for greater understanding of how implicated they are for the various stigma associated abortion stigma on campus

- The benefits of this research will be increased if campuses with similar radio incentives are encouraged to broadcast the drama both for research purpose and improvement of general perception about abortion.

\section{Conclusions}

The findings from the current study affirm the need to build a culture of interdependency amongst students so they can be more supportive of each other. It has demonstrated that the radio as a medium of communication, constitute an agent of socialization and dissemination of values and information to society. The stigmatization and discrimination of students who commits abortion (safe or unsafe) is high and efforts to reduce stigma is very low.

This study advocates that Students Union Governments (SUG) leadership in Tertiary Institutions should chart a course for sexual and reproductive health interventions on campus in order to equip female undergraduates with comprehensive knowledge and skills to reduce the likelihood of abortion and unplanned pregnancies. Various forms of education to increase awareness on issues of abortion and contraceptive usage among students should be adopted by encouraging counselling and love to avoid unsafe abortion, unplanned pregnancies and a culture of silence for students who experience rape and other related youth concerns as highlighted in this study.

\section{Acknowledgements}

The authors acknowledge International Network for the Reduction of Abortion Discrimination and Stigma (INROADS) who are the funders of this research. We sincerely thank and acknowledge the Vice Chancellor, Deputy Vice Chancellor Ekenwuan Campus, the Dean Faculty of Art and the entire Department of Theatre Art and Mass Communication and the Student Union Government, University of Benin for their support during the course of this project. We also appreciate the students of University of Benin especially Theatre Arts and Mass Communication who were members of the theatre crew and provided logistic support throughout the research.

\section{REFRENCES}

[1] Merriam Webster Dictionary, https://www.merriam-webste r.com/dictionary/abortion

[2] "Abortion Policy - Nigeria". The United Nations. Population Division of the Department for Economic and Social Affairs United Nations Secretariat.

[3] R. Ogbu "Illegal abortion in Nigeria: The cringing reality". YNaija. 28 February 2013. https://en.wikipedia.org/wiki/A bortion_in_Nigeria

[4] R. Abiodun "Unsafe abortions cause 20000 deaths a year in Nigeria". BioMedical Journal. p. 988, 2 November 2002. https://en.wikipedia.org/wiki/Abortion_in_Nigeria

[5] S. K. Henshaw, S. Singh, B. A. Oye-Adeniran, I. F. Adewole, N. Iwere, Y. P. Cuca. "The Incidence of Induced Abortion in Nigeria". Guttmacher Institute. Retrieved 11 August 2015.

[6] Guttmacher Institute. "Unwanted Pregnancy and Induced Abortion in Nigeria: Causes and Consequences" (PDF). Retrieved 23 October 2016

[7] World Health Organization. Trends in Maternal Mortality: 1990 to 2013. Estimates by WHO, UNICEF, UNFPA, The World Bank and the United Nations Population Division. Geneva: WHO; 2014.

[8] S. G. Singh. S. Shah IH, et al. Induced abortion: incidence and trends worldwide from 1995 to 2008. Lancet. 2012;379(9816):625-32. PubMed | Google Scholar

[9] World Health Organization DoRHaR. Safe abortion: technical and policy guidance for health systems. World Health Organization.; second edition ed: 132. 2012

[10] A. Norris, D. Bessett, J.R. Steinberg, M.L. Kavanaugh, S. De Zordo, D. Becker. Abortion stigma: a reconceptualization of constituents, causes, and consequences. Women's Health Issues. May-Jun; 21(3 Suppl):S49-54. 2011

[11] E. Berry-Bibee, C.J. Jean, Y. Telemaque, N.M. Nickerson, S. Jean-Louis, E. Lathrop. Stigma surrounding illegal self-induced abortion in urban Haiti. International Journal of Gynaecology and Obstetrics. 131, 2015.

[12] F.O. Okonofua. Prevalence and correlates of the perpetration of abortion among in-school adolescents, Nigeria. International Journal of Adolescent Medical Health, aop. doi: 10.1515/ijamh-2013-0009

[13] C.N. Ngwu. A Study of Public Perception in Abortion in Igbo-Etiti Local Government Area of Enugu State. Nigerian Journal of Social Sciences. University of Nigeria Nsukka. 175 - 188, 2016.

[14] O. Onabajo. Essentials of Broadcast Writing and Production. Lagos. Gabi Concept Ltd. 1999.

[15] L. Simon, K. Daneback. Adolescents' use of the internet for sex education: a thematic and Critical review of the literature. International Journal of Sexual Health, 25:305-319, 2013.

[16] National Universities Commission. Report of the SERVICOM Compliance Evaluation of Federal University of Technology Minna http://servicom.gov.ng/wp-content/u ploads/2017/08/National-University-Commission-FederalUniversity-of-Technology-Minna-Niger-State.pdf 